\title{
肺癌のN因子に対する経食道的超音波内視鏡検査 の有用性に関する検討
}

\author{
崎尾 秀 彦，山口豊
}

\section{要旨}

肺癌症例 32 例飞対し，経食道的超音波内視鏡検查（以下，E-EUS と略）を施行し，N因子特に縦隔 リンパ節転移の有無に関して観察を試み，その有用性について検討した。 E-EUS では，描出範囲は制 限され，一般には，大動脈下リンパ節（\#5）および気管分岐部リンパ節（\#7）が観察されるに過ざなか った。乙れらの部位では，リンパ節の輪郭は明膫に描出され，その最大の断面にて長径・短径の計測が 可能で，平均直径 $10 \mathrm{~mm}$ 以上を転移陽性と判定すると，勒および\#7の sensitivity, specificity, accuracy はそれぞれ，85.7\%，80.0\%，81.3\%㧍よび100\%，93.1\%，93.8\%と良好な成績で，CTとの比較であ， 鹊については描出能・正診率に打いて優れていた。径 $20 \mathrm{~mm}$ 以上の著明に腫大したリンパ節では，内 部エコーが不均一で壊死による空洞形成を認めた症例むあったが，軽〜中等度腫大したリンパ節では， 内部エコーの性状で転移の有無を判定するのは困難であった．

索引用語：肺癌，縦隔リンパ節，超音波内視鏡，平均直径，正診率． lung cancer， mediastinal lymph node, endoscopic ultrasonography, mean diameter, accuracy.

\section{緒言}

肺癌症例における肺門および縦隔りンパ節 転移の有無（N因子）の評価・診断は，術前 staging や，それに基づく治療法の選択や予後 の判定に重要である ${ }^{1 \sim 5)} .1975$ 年頃より出現し た CT は，その優れた空間分解能により，従来 の各種画像診断法の言わば死角であった縦隔内 病変の観察を容易とし，かつその非侵襲性，簡 便性からの普遍的な検査法となってきた。肺癌 の縦隔リンパ節の $\mathrm{CT}$ 等, 各種画像診断能につ いては，その有用性および限界について多くの 検討がなされている ${ }^{6 \sim 16)}$. 縦隔リンパ節転移の 有無をその大きさから判定するには，大血管や 脂肪組織とのコントラストに優れ，リンパ節が より明瞭に描出可能な検査法が必要とされる.

干葉大学医学部肺癌研究施設外科

于280 干葉市亥鼻1-8-1

原稿受付 1988年 1 月11日

原稿採択 1988年4月6日
このような目的から，従来肺癌等呼吸器疾患 に対し，経体表的アプローチではその骨性胸廓 や気道内含気等の阻害因子のため, 胸水や胸壁 〜胸壁直下の病変の診断にのみその利用が限ら れていた超音波検查法の応用範囲を広げ，その 超音波探触子を小型化し内視鏡下に経食道的に 挿入し, 肺癌症例において縦隔リンパ節の観察 を行ない，その有用性について検討を行なった。

\section{研究対象および方法}

昭和 59 年 6 月より昭和 62 年 7 月までの約 3 年 間に経食道的超音波内視鏡 (Esophageal endoscopic ultrasonography, 以下，E-EUS と略）を 施行した肺癌症例は47例で，乙のうち左側肺原 発の肺癌切除例 32 例を対象とした。切除例 32 例 の組織型別の内訳は，扁平上皮癌15例，腺癌11 例，その他 6 例であった。

E-EUS の機種は，先端に径 $12 \mathrm{~mm}$ ，長 さ $40 \mathrm{~mm}$ の円筒状の周波数 $5 \mathrm{MHz}$ のリニア 


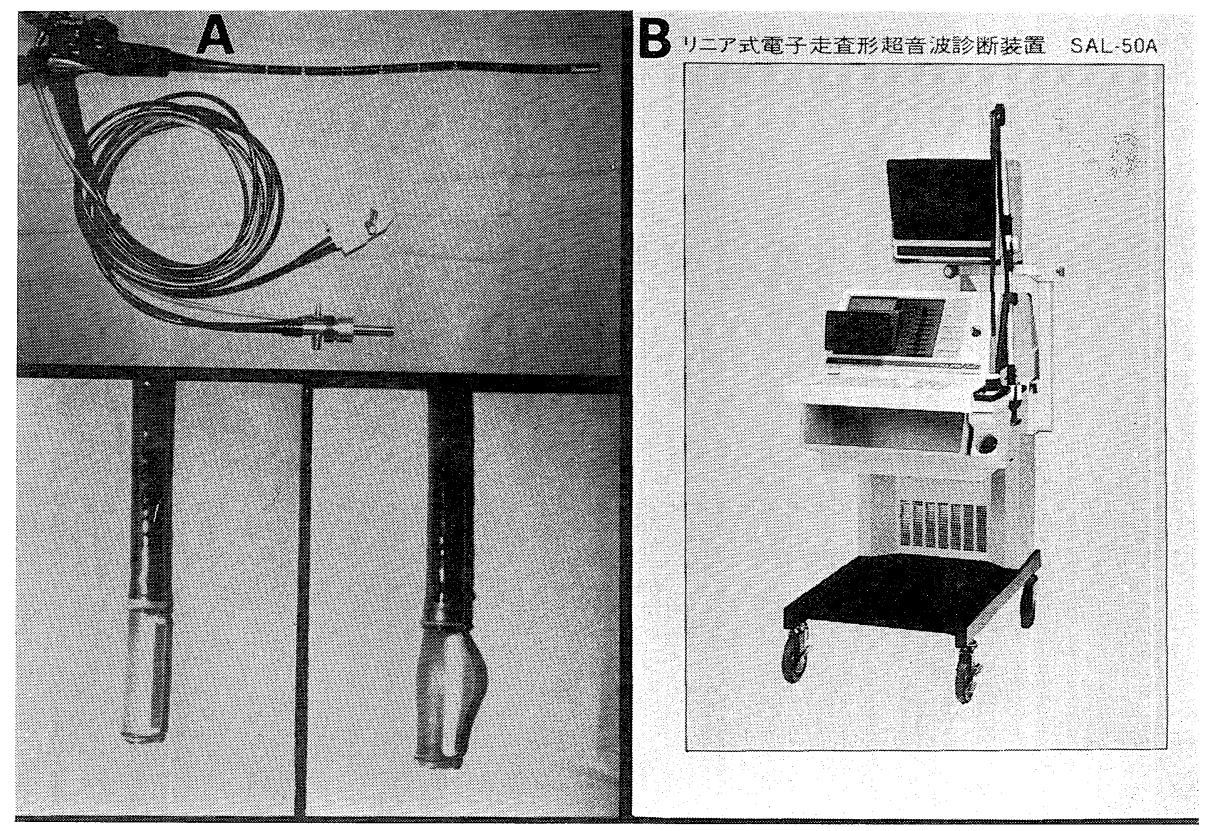

\begin{tabular}{|c|c|}
\hline \multicolumn{2}{|c|}{ 超音波ブローブに関寸る仕様 } \\
\hline 走查方式 & リニア式電子走査方式 \\
\hline 楇 波 数 & 中心 $5 \mathrm{MHz}$ (広带域) \\
\hline 視 野 幅 & 約 $32 \mathrm{~mm}$ \\
\hline レン ズ & 凸型レンズ、焦点䣋 $30 \mathrm{~mm}$ \\
\hline バルーン & 着・脱可 \\
\hline \multicolumn{2}{|c|}{ ファイバースコーブ・形状に関する什様 } \\
\hline 全長 & 約 $785 \mathrm{~mm}$ \\
\hline 有 効 長 & 約 $550 \mathrm{~mm}$ \\
\hline 先端部径 & $\phi 12 \mathrm{~mm}$ \\
\hline 軟性部径 & $\phi 11.7 \mathrm{~mm}$ \\
\hline 彎 曲 角 & 上 $130^{\circ}$ 、下 $90^{\circ}$ 、左右各 $90^{\circ}$ \\
\hline ライトガイド管長 & $2,000 \mathrm{~mm}$ \\
\hline 視野 & 前方視 $60^{\circ}$ \\
\hline
\end{tabular}

図 1 E-EUS に使用した機種 A：先端に超音波探触子を装着した食道用内視鏡. 下段左はバルーン deflate 時, 右は inflate 時. $\mathrm{B}$ : 超音波診断装置

型超音波探触子を取り付けた食道用内視鏡 (MACHIDA. EPB-503-FS) を使用した。探触 子には食道壁と密着させるためのバルーンを装 着した（図-1A). 起音波䧐断装置 (TOSHIBA. SAL-50A) を組み合わせ使用し，ポラロイド （タイプ 667）で撮影・記録した（図(1B).

検査手技は通常の食道内視鏡検査と同様であ が，しかし先端の長さ $40 \mathrm{~mm}$ の硬性の探触子 が插入時に患者に苦痛を与えるととからそれを
軽減するために，前投薬には Atropine sulfate $0.5 \mathrm{mg}$ の他 Pentazocine $15 \mathrm{mg}$, Hydroxyzine hydrochloride (Atarax-P) $25 \mathrm{mg}$ を併用した. 食道内插入後, 必要に応じ注水口より蒸留水を 5 10 $\mathrm{m} l$ 注入し, 軽度食道壁が圧迫されるま でバルーンを膨らませ食道壁と密着させて，心 ・大血管を指標に縦隔リンパ節および腫瘤の観 察を行なった。

図-2には縦隔の構造の理解に必要である代表 


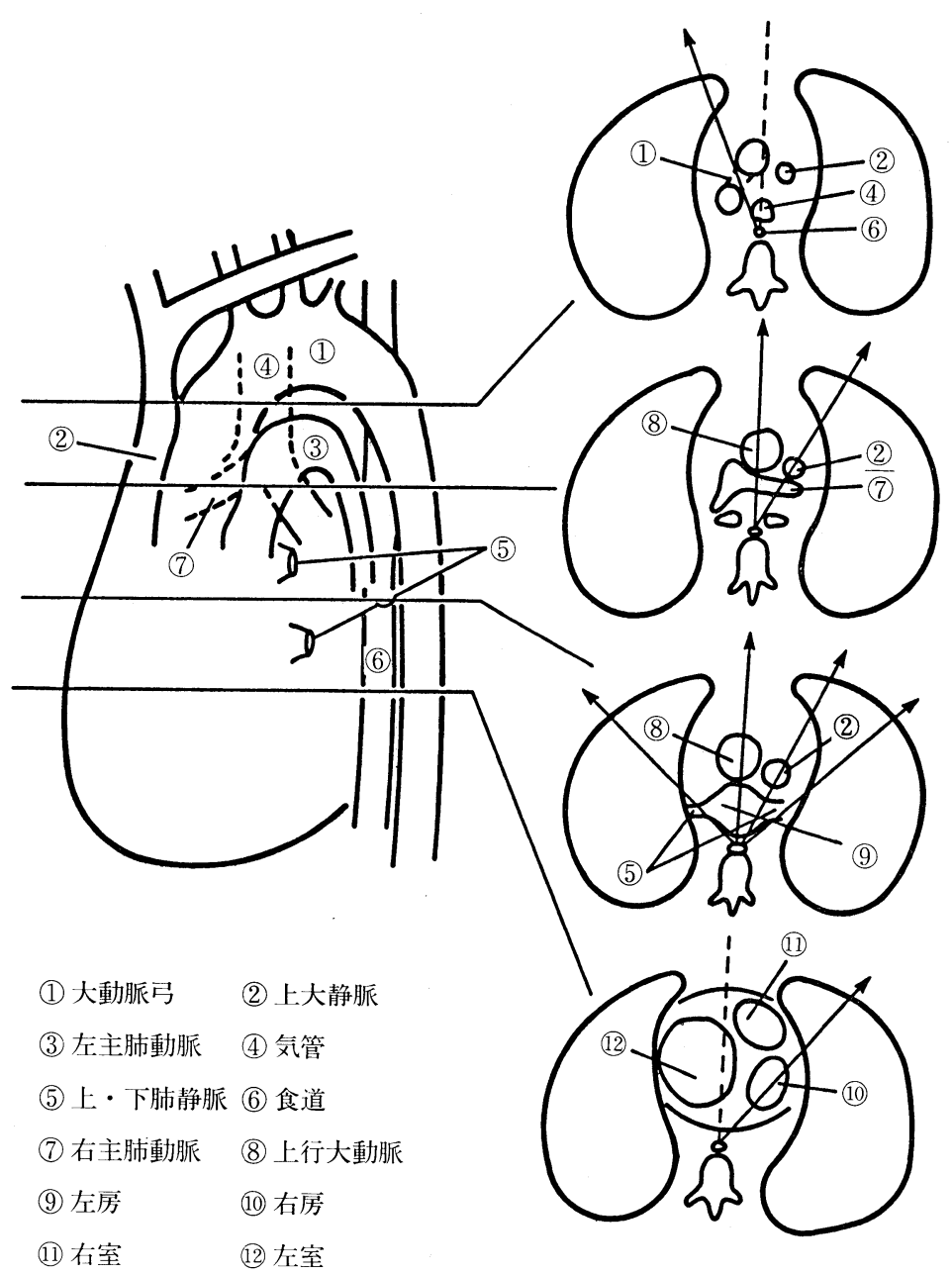

図2 緃隔における超音波走查部位と方向 $\rightarrow$ : 射入方向を示す.

的な水平断面レベルと，同部における頭側から 見た CT 像を対比させ，探触子の方向を示した。 さらに図-3, 4, 5,6には以上の走査によって得ら れた E-EUS 像をシェーマととあに示した. 図 -3,4は探触子の方向を一定にし，その高さを移 動, 図-5,6は同一の高さでその方向を変えて観 察したものである.

また，縦隔りンパ節の描出可能な範囲・大き さを知るために，雑種成犬を用いて，全麻下左 開胸下に，縦隔リンパ節の各部位に蒸留水で膨 らませた様々な大きさのバルーンを設置し， E-EUS により観察しうる大きさの検討を行な った，さらに，リンパ節の大きさの計測は，EEUS によるとリンパ節を連続して観察すると
とができるので，その最大断面の長径・短径が 計測可能である. 切除例 32 例について井および \#7の長径と短径を計測し, 平均直径を算出して リンパ節の大ささとみなし，転移の有無との相 関について検討した. なお同一領域に数個のリ ンパ節を認めた場合は，そのうちの最大のあの を計測し検索対象とした，描出されたリンパ節 は平均直径 $10 \mathrm{~mm}$ 以上を転移陽性と判定する ことにした。なお臨床病期分類およびリンパ節 の命名は肺癌取り扱い規約に従った.

成績

1）描出可能なリンパ節：

犬を用いた基礎的検討では，大動脈下リンパ 


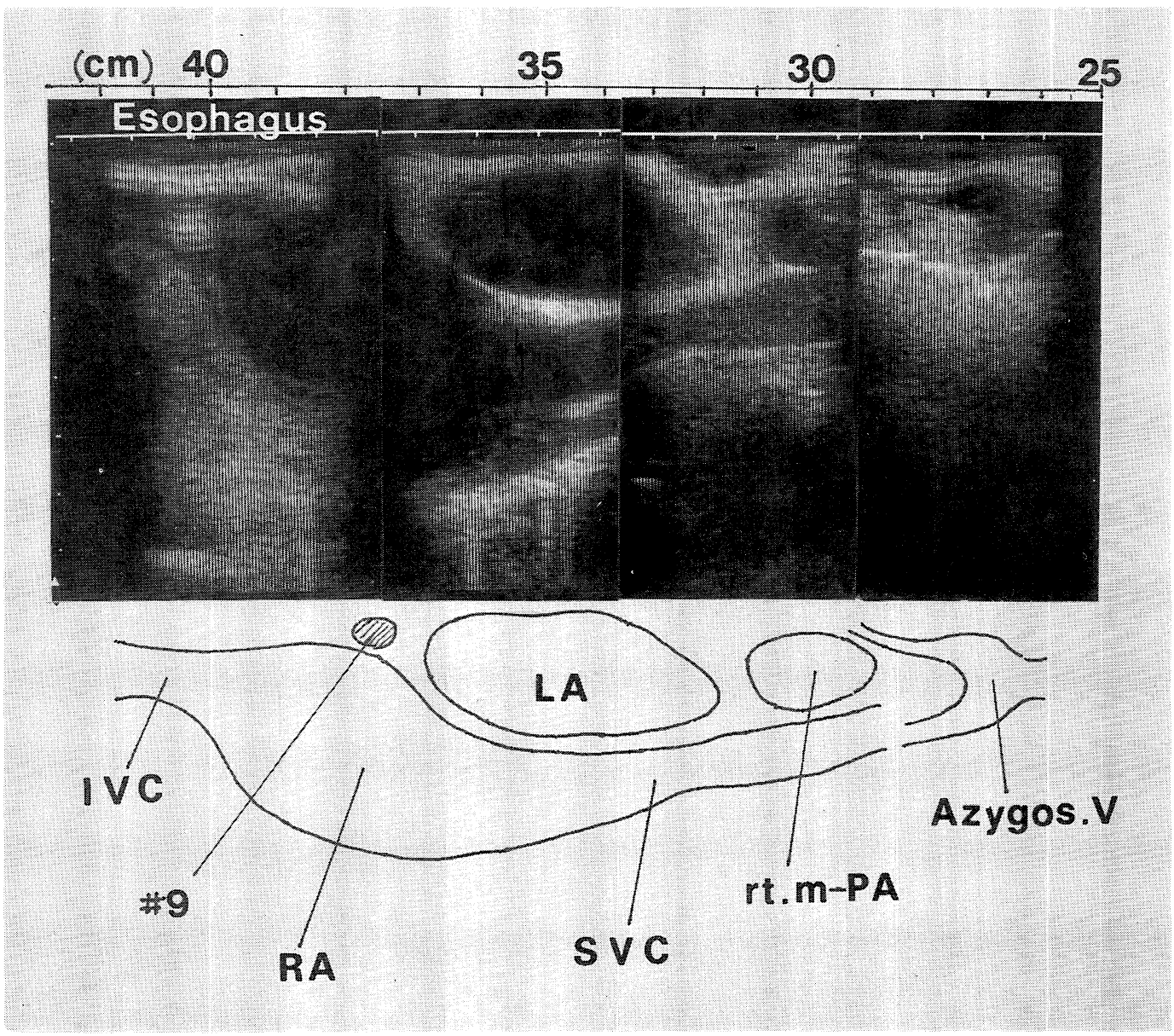

図 3 E-EUS 所見. 左側は尾側，右側は頭側，上方は食道内腔で数値は門歯からの距離を示す. 探触子を正中より約30度右方に向けた場合の縱断面像. Azygos. V: 奇静脈，rt. m-PA：右 主肺動脈, SVC：上大静脈，La：左房, RA：右房, IVC：下大静脈

節（\#5），気管分岐部リンパ節（\#7）の部位にお いては，いずれも，バルーンは径 3〜4 $\mathrm{mm}$ から 描出され始め，径 5〜 $6 \mathrm{~mm}$ になると輪郭が明 瞭となった（艮一7）。なお，バルーンはほぼ球 型であるのでその長径・短径の E-EUS 上の测 定值と実測值との誤差は 1 2 mm 以内にとど まった。また，他の部位に関しては，右側気管 気管支リンパ節（\#4），気管前リンパ節（\#3）で は径を $20 \mathrm{~mm}$ に増しても描出や同定は不可能 であった。

臨床例においては，切除例32例中， E-EUS にて描出されたリンパ節の部位と描出例数は, \#5で31例 (96.9\%)，\#7は25例 (78.1\%), 左主 気管支周囲リンパ節（\#10）は10例（31.3\%）,
左側 4 は 5 例 (15.6\%)，右側\#10は3 例（9.4 $\%)$ ，食道傍リンパ節（\#8）は2例 (6.3\%), であった．以上の結果から以後は多くの症例で 描出可能であった井と井 7 にいて検討するとと にした。

2）リンパ節腫脹の大きさと転移の有無との相 関 :

\#5および\#7の摘出後の病理組織学的検索によ って診断された実際の転移の有無と, E-EUS で計測したそれらの長径，短径との相関につい ての検討では, 転移 (十) 群は, 長径・短径と 屯10 mm 以上でほぼ円形で，転移（一）群は， 長径でも $10 \mathrm{~mm}$ 以下のととが多く，長径が10 $\mathrm{mm}$ 以上でも短径が小さい楕円形を呈する傾问 


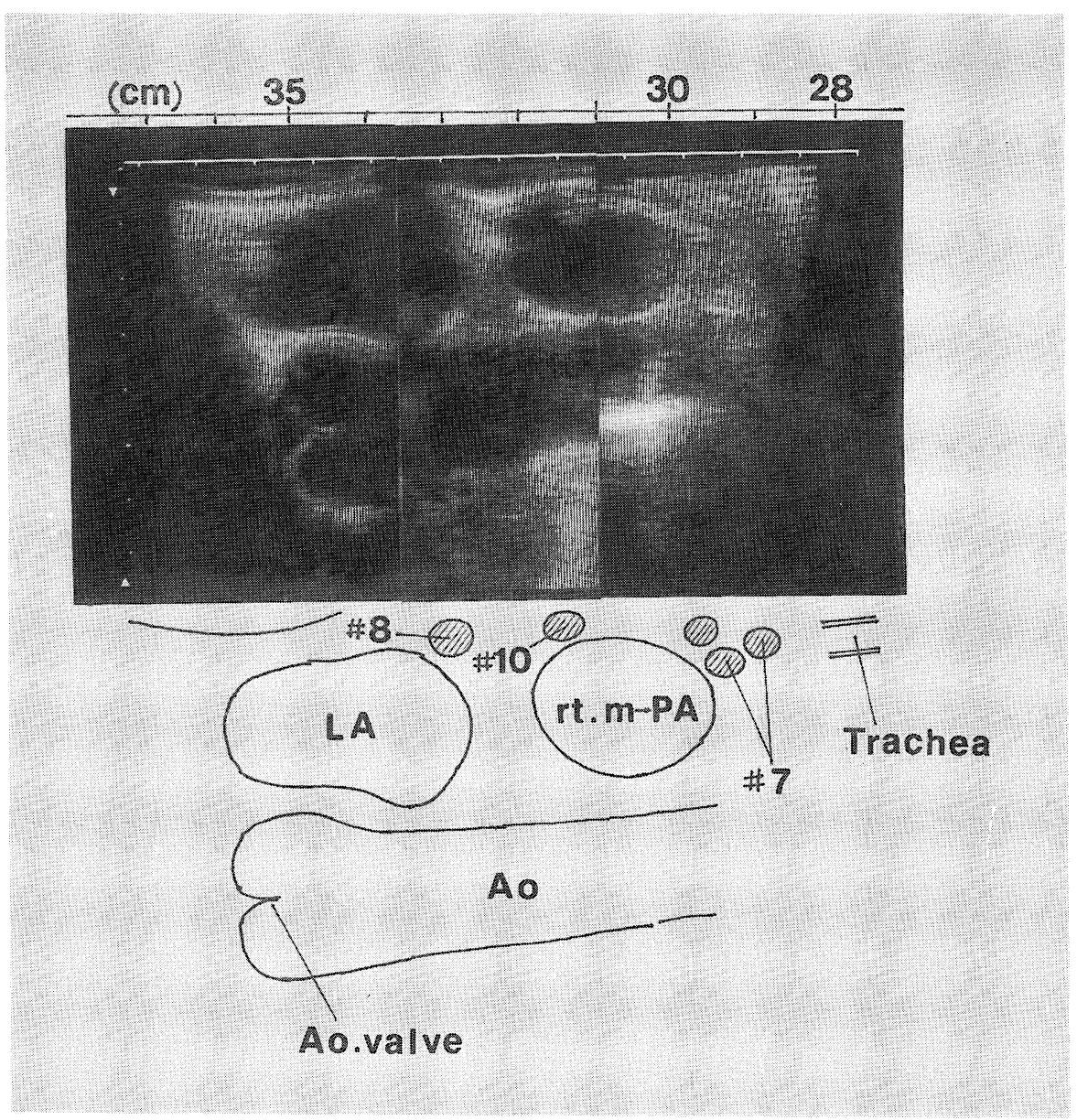

図 4 E-EUS所見：ほぼ正中に打ける縦断面像. rt.m-PA : 右主肺動脈, LA : 左房, Ao: 大動脈, Ao. valve : 大動脈弁

れが認めらた（図-8).

また，転移の有無別による E-EUS での計測 值抒よび摘出リンパ節の実測值の平均直径の比 較では，いずれす転移（+）の方が大きく，転 移の有無を判定する大きさの基準值は，平均直 径 $10 \mathrm{~mm}$ 前後とするのが妥当と考えた. しか し，転移（一）群では細長いリンパ節が多いた め，E-EUS 上の測定值が実測值よりも小さめ に計測され，より球状に近い形態を示す転移

（十）群では両者の測定值の誤差がより少ない 傾向を示した（表-1）。しかし実際には，EEUS 上の所見による転移の有無の判定と実際 の病理結果の一致しない例も認められた（図 -9 , 10, 11).
表1転移の有無から見た 55 と 7 の大きさ（平 均直径) の比較

1) E-EUS 上の計測值

\begin{tabular}{c|c|c}
\hline & 転 移 (-) & 転 移 $(+)$ \\
\hline$\# 5$ & $\begin{array}{c}5.90 \pm 3.56 \\
(\mathrm{n}=25)\end{array}$ & $\begin{array}{c}10.86 \pm 2.64 \\
(\mathrm{n}=7)\end{array}$ \\
$\sharp 7$ & $\begin{array}{c}4.47 \pm 3.10 \\
(\mathrm{n}=29)\end{array}$ & $\begin{array}{c}14.0 \pm 0 \\
(\mathrm{n}=3)\end{array}$ \\
\hline
\end{tabular}

2）摘出リンパ節の実測值

\begin{tabular}{c|c|c}
\hline & 転 移 (-) & 転 移 $(+)$ \\
\hline$\sharp 5$ & $\begin{array}{c}9.17 \pm 3.17 \\
(\mathrm{n}=3)\end{array}$ & $\begin{array}{c}14.30 \pm 0.75 \\
(\mathrm{n}=2)\end{array}$ \\
$\sharp 7$ & $\begin{array}{c}8.75 \pm 1.35 \\
(\mathrm{n}=4)\end{array}$ & $\begin{array}{c}14.0 \pm 0 \\
(\mathrm{n}=1)\end{array}$ \\
\hline
\end{tabular}




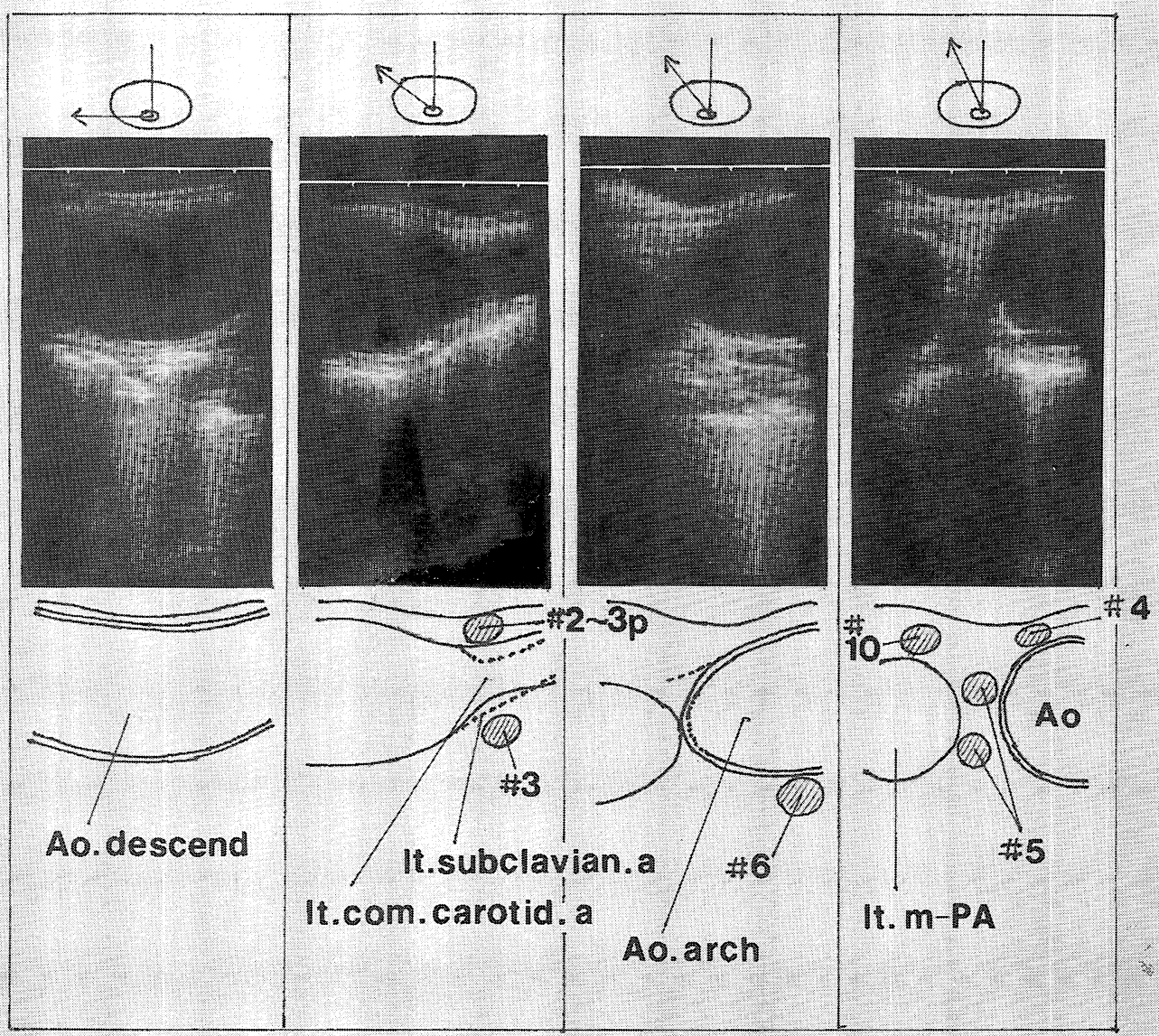

図 5 E-EUS 所見 : 大動脈弓の高さで探触子の向きを左から正中苦向へ移動した像. Ao. descend: 下行大動脈, lt subclavian. a : 左鎖骨下動脈, lt. com. carotid. a : 左総頸動脈, Ao. arch : 大動脈弓, lt. m-PA：左主肺動脈, Ao：大動脈

3）\#5と\#7についての正諸と CT との比較 : 転移の有無に関連して，E-EUS と CT にお ける正診率を比較したととろ（表一2），\#7亿関 しては, E-EUS およびCT とも極めて高い正 診率で特に差は認められないが，\#5に関しては， CT では false negative が 4 例 (12.5\%)で, sensitivity は42.9\%と低值であり，一方， EEUS では false negative は1例 (3.1\%), で, sensitivity は85.7\%と高值を示した。また EEUS による\#5 false positive は5 例 (16.5 \%)で，その組織型別の内訳は，扁平上皮癌 2 例, 腺癌 3 例で特に差は認められなかった. 術 前と術後検索による $\mathrm{N}$ 因子の一致率の検討で は (表-3), CT では overestimation が13例
表2 \#5および $¥ 7$ における CT と E-EUS の正 彰率の比較

\begin{tabular}{|c|c|c|c|c|}
\hline & \multicolumn{2}{|c|}{$\$ 5$} & \multicolumn{2}{|c|}{$\sharp 7$} \\
\hline & $\mathrm{CT}$ & E-EUS & $\mathrm{CT}$ & E-EUS \\
\hline True positive (T.P.) & 3 & 6 & 3 & 3 \\
\hline True negative(T. N.) & 20 & 20 & 28 & 27 \\
\hline False positive (F. P.) & 5 & 5 & 1 & 2 \\
\hline False negative(F.N.) & 4 & 1 & 0 & 0 \\
\hline Sensitivity $^{1)}$ & 42.9 & 85.7 & 100.0 & 100.0 \\
\hline Specificity ${ }^{2)}$ & 80.0 & 80.0 & 96.6 & 93.1 \\
\hline Accuracy ${ }^{3)}$ & 71.9 & 81.3 & 96.9 & 93.8 \\
\hline
\end{tabular}
$1)=\frac{\text { No of T.P. }}{\text { No of T. P. }+ \text { No of F. N. }} \times 100$

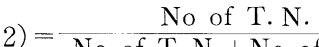
$2)=$ No of T. N. + No of F.P. $\times 100$
$3)=\frac{\text { No of T. P. }+ \text { No of T. N. }}{\text { total No of instance }} \times 100$ 
表 3 CT 抽よ゙ E-EUS における $\mathrm{cN}$ と $\mathrm{PN}$ の比較

\begin{tabular}{|c|c|c|c|c|c|}
\hline $\mathrm{CT}$ & $\mathrm{cN} \rightarrow \mathrm{pN}$ & $\operatorname{Epi}(\mathrm{n}=15)$ & $\operatorname{Ad}(n=11)$ & Others $(n=6)$ & Total $(\mathrm{n}=32)$ \\
\hline \multirow{4}{*}{ Under-estimation } & $\mathrm{N}_{0} \rightarrow \mathrm{N}_{1}$. & 1 & 0 & 1 & 2 \\
\hline & $\mathrm{N}_{0} \rightarrow \mathrm{N}_{1}$ & 0 & 1 & 0 & 1 \\
\hline & $\mathrm{N}_{1} \rightarrow \mathrm{N}_{2}$ & 1 & 1 & 1 & 2 \\
\hline & Total & $2(13.3 \%)$ & $2(18.2 \%)$ & $1(16.7 \%)$ & $5(15.6 \%)$ \\
\hline \multirow{4}{*}{ Over-estimation } & $\mathrm{N}_{1} \rightarrow \mathrm{N}_{0}$ & 6 & 2 & 1 & 9 \\
\hline & $\mathrm{N}_{2} \rightarrow \mathrm{N}_{0}$ & 0 & 0 & 2 & 2 \\
\hline & $\mathrm{N}_{2} \rightarrow \mathrm{N}_{1}$ & 2 & 0 & 0 & 2 \\
\hline & Total & $8(53.3 \%)$ & $2(18.2 \%)$ & $3(50.0 \%)$ & $13(40.6 \%)$ \\
\hline \multirow{4}{*}{ Correct-estimation } & $\mathrm{N}_{0} \rightarrow \mathrm{N}_{0}$ & 1 & 5 & 1 & 7 \\
\hline & $\mathrm{N}_{1} \rightarrow \mathrm{N}_{1}$ & 1 & 0 & 0 & 1 \\
\hline & $\mathrm{N}_{2} \rightarrow \mathrm{N}_{2}$ & 3 & 2 & 1 & 6 \\
\hline & Total & $5(33.3 \%)$ & $7(63.6 \%)$ & $2(33.3 \%)$ & $14(43.8 \%)$ \\
\hline E-EUS & $\mathrm{cN} \rightarrow \mathrm{pN}$ & $\operatorname{Epi}(n=15)$ & $\operatorname{Ad}(n=11)$ & Others $(n=6)$ & Total $(n=32)$ \\
\hline \multirow{4}{*}{ Under-estimation } & $\mathrm{N}_{0} \rightarrow \mathrm{N}_{1}$ & 2 & 0 & 1 & 3 \\
\hline & $\mathrm{N}_{0} \rightarrow \mathrm{N}_{2}$ & 0 & 0 & 0 & 0 \\
\hline & $\mathrm{N}_{1} \rightarrow \mathrm{N}_{2}$ & 0 & 0 & 0 & 0 \\
\hline & Total & $2(13.3 \%)$ & $0(0 \%)$ & $1(16.7 \%)$ & $3(9.4 \%)$ \\
\hline \multirow{4}{*}{ Over-estimation } & $\mathrm{N}_{1} \rightarrow \mathrm{N}_{0}$ & 0 & 0 & 0 & 0 \\
\hline & $\mathrm{N}_{2} \rightarrow \mathrm{N}_{0}$ & 1 & 3 & 0 & 4 \\
\hline & $\mathrm{N}_{2} \rightarrow \mathrm{N}_{1}$ & 2 & 0 & 0 & 2 \\
\hline & Total & $3(20.0 \%)$ & $3(27.3 \%)$ & $0(0 \%)$ & $6(18.7 \%)$ \\
\hline \multirow{4}{*}{ Correct-estimation } & $\mathrm{N}_{0} \rightarrow \mathrm{N}_{0}$ & 6 & 4 & 4 & 14 \\
\hline & $\mathrm{N}_{1} \rightarrow \mathrm{N}_{1}$ & 0 & 0 & 0 & 0 \\
\hline & $\mathrm{N}_{2} \rightarrow \mathrm{N}_{2}$ & 4 & 4 & 1 & 9 \\
\hline & Total & $10(66.7 \%)$ & $8(72.7 \%)$ & $5(83.3 \%)$ & $23(71.9 \%)$ \\
\hline
\end{tabular}

(40.6\%)ああり，特に $\mathrm{cN}_{1}$ と判定したあのが， 実際には $\mathrm{pN}_{0}$ であった症例が 9 例の症例 (28.1 \%)であった。組織型別では扁平上皮癌におい て overestimation の多い傾向が認められた. 一 方，E-EUS では，肺門リンパ節の描出や同定 が困難で，\#10の腫大を認めることのできた 10 例はすべて同時に縦隔リンパ節の腫大を認めた ため，E-EUS にて $\mathrm{cP}_{1}$ と判定した症例は 1 例 あなかった。たまたま $\mathrm{pN}_{1}$ が 5 例（15.6\%） と少なかったため， E-EUS による correct estimation が23例（71.9\%）と良好な結果にな った.

\section{考按}

肺癌の縱隔リンパ節転移の䛦断には，CT ス キャンが今日では広く普及してきている ${ }^{6 \sim 16)}$.

N因子の診断に対する CT の有用性を検討した 報告では， CT 施行例と非施行例での $\mathrm{cN}$ と $\mathrm{pN}$ との比較では正診率にあまり差がないと言 われている ${ }^{11,122}$ 。すなわち，胸部単純 $\mathrm{X}$ 線や断 層撮影のみの場合に比較し CT の併用により縦 隔リンパ節の描出能が向上し，同部のリンパ節 に対する underestimation は減少したが，その 反面 $\mathrm{pN}_{0}$ や $\mathrm{pN}_{1}$ に対する overestimation が増 


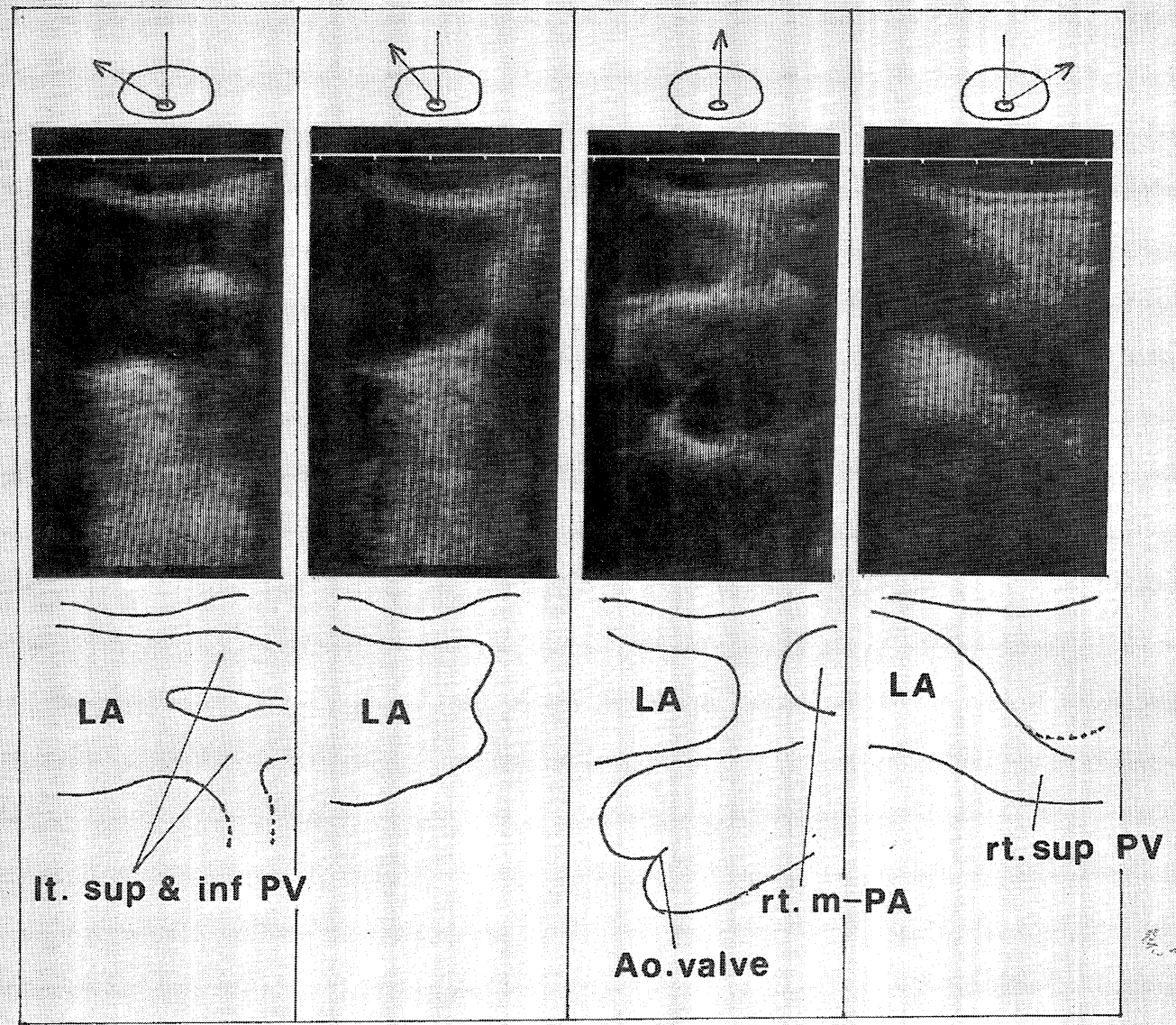

図6 E-EUS 所見：左房の高さで探触子の向きを左から右へ移動した像. LA：左房, It. sup \& inf PV: 左上. 下肺静脈, Ao. valve: 大動脈弁, rt. m-PA：右主肺動脈 rt. sup PV: 右上 肺静脈

加し，全体としてほぼ同じような正診率である という.

1980年，DiMagno の報告 ${ }^{17)}$ 以来，超音波内 視鏡検査は，探触子の小型化，画像の鮮明化な どの装置の改良とと屯に臨床応用されるように なり，今日では，食道癌，胃癌および直腸癌等 の消化器疾患を中心に，リンパ節転移の診断な ぞに対する有用性が報告されるようになってき $た^{18 \sim 20)}$.

肺癌において屯，経食道的超音波内視鏡 (EEUS）を行ない，縦隔リンパ節転移の診断に対 する有用性が報告されている21,22). しかし，EEUS では，探触子から $4 \sim 5 \mathrm{~cm}$ の距離のある
あのでは，画像上リンパ節の描出が困難である か不可能であるといった装置の性能上の問題の 他，含気部，気管～気管支軟骨，リンパ節や大 動脈の石灰化などの超音波の伝搬を阻害する種 々の因子の存在により描出・同定されるリンパ 節の範囲がかなり制限される，すなわち 5 すや\#7 では径 4 5 mm のものでも明瞭に描出された が，右側\#10，\#2〜\#4などでは径 $15 \mathrm{~mm}$ 前後の あのであ描出不可能であった，従って，一般に は井 5 押よび\#7が観察されるに過ぎず，本研究に おいては主として非と胡について検討を行なっ た.

E-EUS では, 脂肪組織や血管との分解能に 


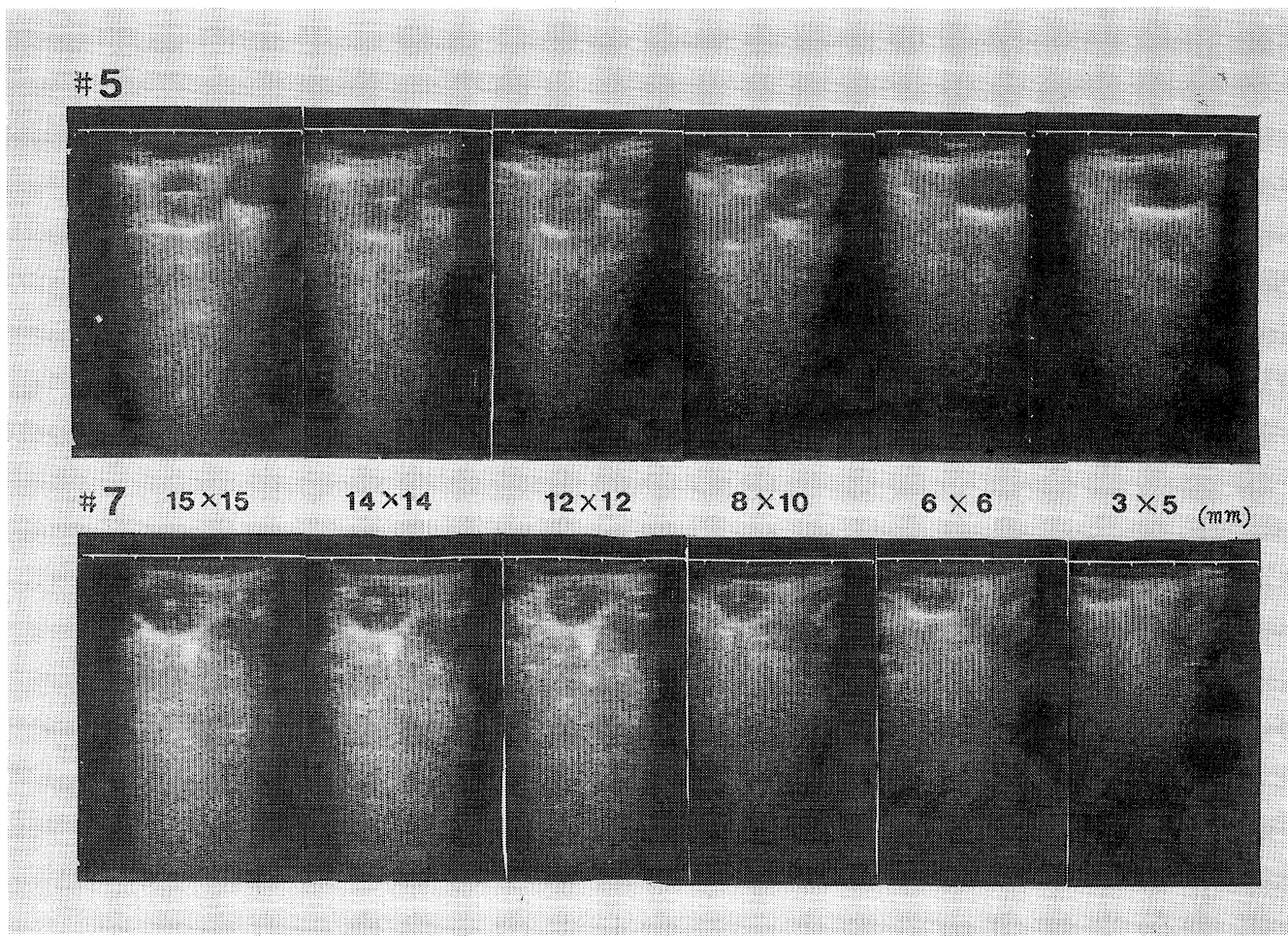

図7 犬の $\$ 5 ， \# 7$ 亿設置したバルーンの大きさと E-EUS 所見の対比

優れているためリンパ節の輪郭屯明瞭に描出さ れ，挆触子の方向を移動することにより一つの リンパ節を一断面だけでなく全体像として観察 でき,その最大の断面における長径・短径が計測 可能である. 今回はそれらから算出した平均直 径により転移の有無の判定を行なった。しかし， 摘出されたリンパ節が球状に近い形状を示す, すなわち転移（十）の可能性が高い場合は，EEUS による測定值と実際の大きさはほぼ一致 していたが，水平方向に細長い扁平な場合には 実測值よりも小さめに計測され，誤差が認めら れた。

リンパ節の転移の有無をその大きさから判定 する場合には，大きさの基準值の設定が必要で ある. CT における基準值は報告により様々 で ${ }^{6 \sim 16)}$ ，基準值が小さければ小さいほど overestimationすなわち false positive 例が増加し, sensitivity は向上するが， specificity が低下す る.

本研究では, (ilazer ${ }^{23)} や G e n e s e u x{ }^{24)}$ らの正
常例における縦隔リンパ節の大きさに関する報 告を参考にして，平均值径 $10 \mathrm{~mm}$ 以上を転移 （十）と判定することにして検討を行なった. その結果, \#5と\#7の sensitivity, specificity, accuracy は，それぞれ85.7\%，80.0\%，81.3\%， および100.0\%，93.1\%，93.8\%であり，良好 な結果であった，CT に打ける正診率と比較す ると，\#5は，大動脈弓と左主肺動脈幹との間に 介在するため CT では不明瞭となるととが多い が (partial volume effect), E-EUS では血管や 脂肪組織との分解能が優れているため，CT に 比べ見落としが少なく，描出能にも優れていた。

正診率向上のための，リンパ節転移の有無に 関する判定基準の再検討および質的診断の試み がある，前者に関しては，単に平均直径だけか ら転移の有無を判定するのではなく，笠島ら ${ }^{21}$ は，長径・短径比やリンパ節が多発・融合して いる所見を加え判定すると述べている。また， 部位により正常リンパ節の大きさが異なるので 部位別の区分 ${ }^{9)}$ の必要性, あるいは腺癌ではり 

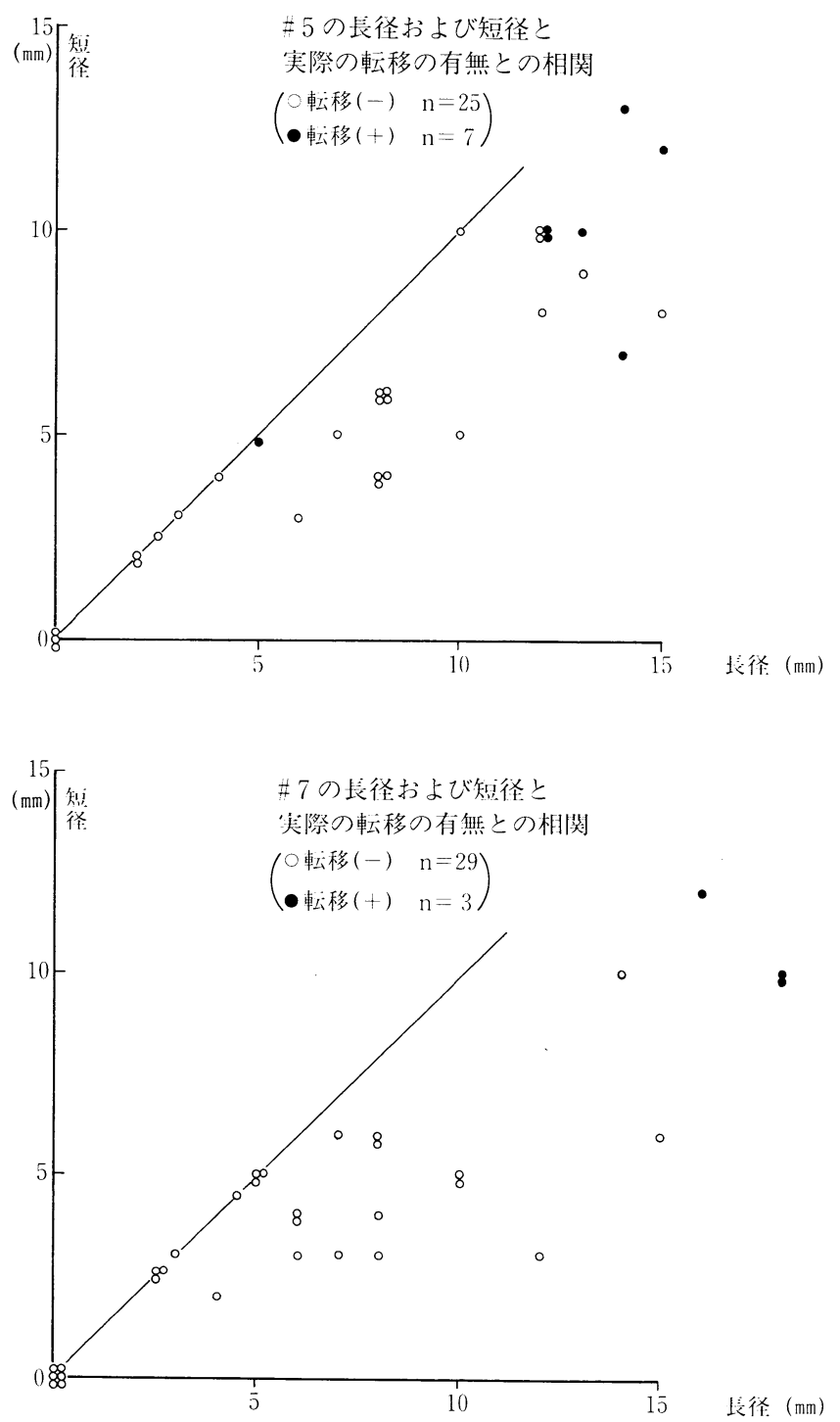

図 8 \#5 と7 の大きさ一長径・短径一と転移の有無との相関

ンパ節腫大を来さずにスキップあるいは micrometastasis で転移する傾向もあり，組織型 別による区分 ${ }^{6)}$ あ必要であるとの主張あある. 質的診断に関しては，造影剂併用による試みの 報告もあるが25，しかし一般には内部エコ一の 性状で転移の有無を鑑別することは困難である 之考える. われわれの症例で屯, 径 $20 \mathrm{~mm}$ 以 上の著明な腫大リンパ節で，内部エコーが不均 一で壊死による hypoechoic area（空洞）を認め た症例，径 $10 \mathrm{~mm}$ 前後のリンパ節でも，その 周囲の hyperechoic layer の增大を認めた例,
中心部に hyperechoic area 認めた例, いくつ かのリンパ節が融合していた例などがあった． しかしてれらは症例によって異なり必ずしも一 定した所見ではなかった。また，軽〜中等度腫 大したリンパ節に関しては，その内部および周 囲のエコーの性状から転移の有無を判定するの は困難であった。

\section{結 論}

肺癌症例32例に対し，E-EUS を施行し，N 因子特に縦隔リンパ節の観察を行ない以下の結 


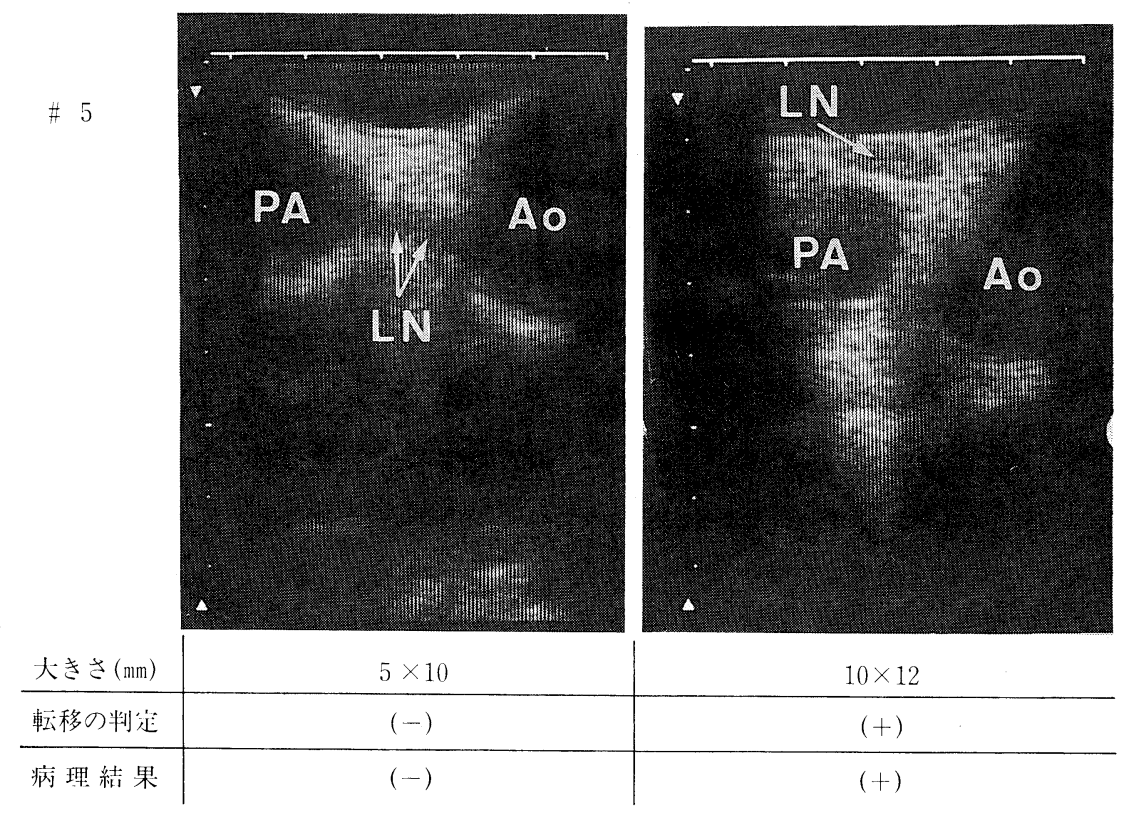

図 9 E-EUS 上の計測值加ら転移の判定と実際の病理組織所見の結果との比較 : \#5に㧍ける一致 例. PA：肺動脈, Ao：大動脈, LN：リンパ節

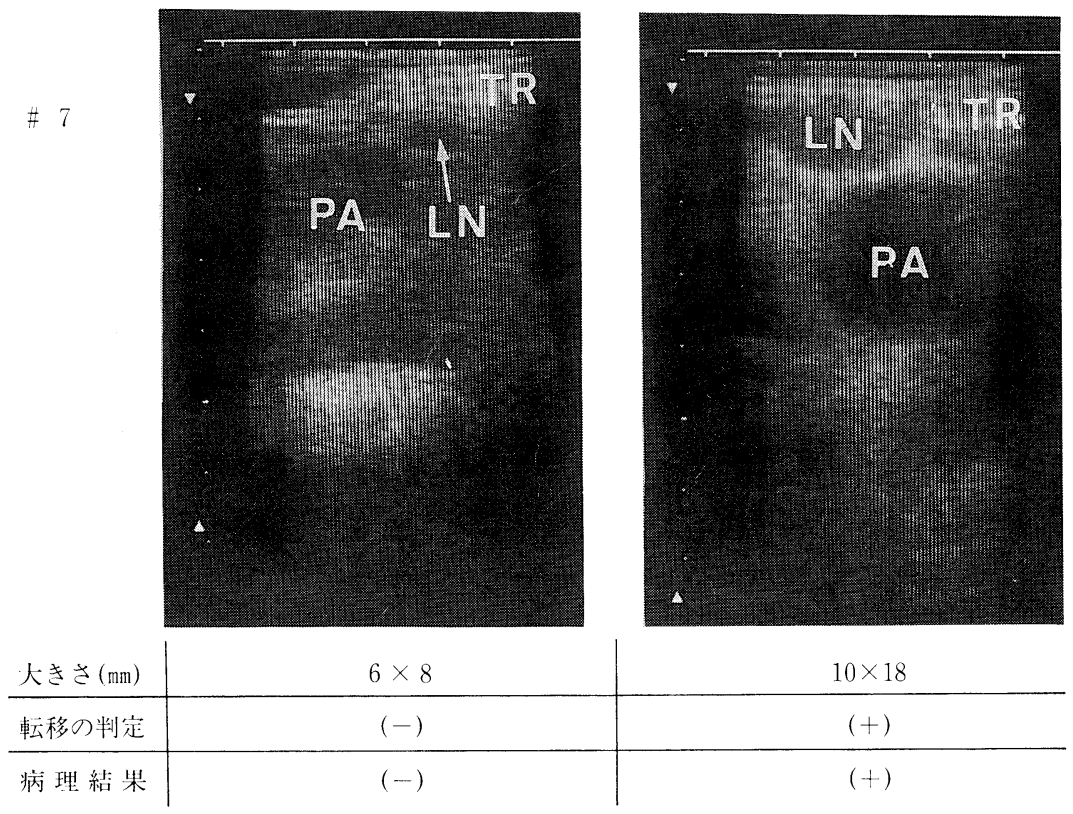

図10 \#7 における一致例. TR：気管

論が得られた.

(1)一般には，大動脈下リンパ節（\#5）と気管 分岐部リンパ節（\#7）が観察されるに過ぎない。 しかし胢に関してはCTより描出能・正診率が
優れていた.

(2)リンパ節の輪郭は明瞭に描出され，その最 大の断面にて長径・短径の計測が可能であった.

(3)平均直径 $10 \mathrm{~mm}$ 以上を転移 (十) と判定 


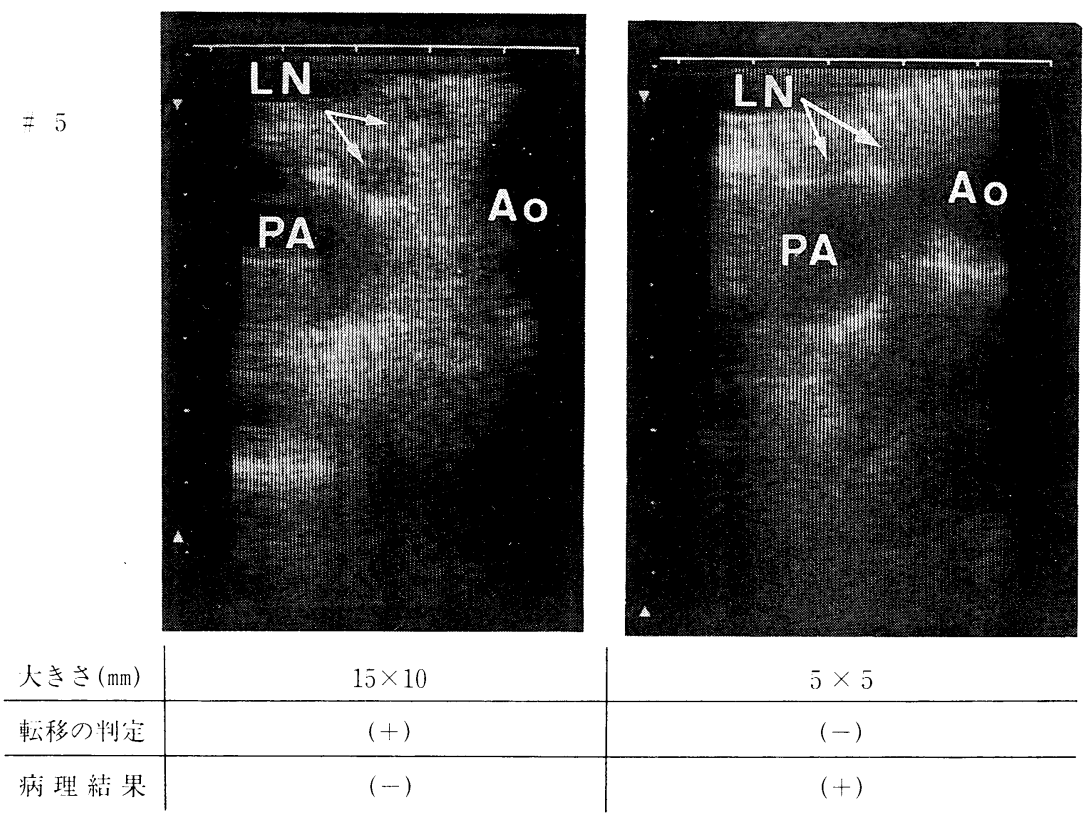

図11 \#5における不一致例

すると，\#5および\#7の sensitivity， specificity， accuracy は，それぞれ85.7\%，80.0\%，81.3 \%および100\%，93.1\%，93.3\%と良好であっ た。

(4)軽〜中等度腫大したリンパ節では，内部エ コーの性状による転移の有無の判定は困難であ った。

本論文の要旨は第26回日本肺癌学会総会にお いて発表した。

\section{文献}

1）山口 豊：肺癌外科療法に拈けるN因子，臨床外 科 Year Book 1981-82, メジカルビュー社, 東京, 1981, pp. 164-174.

2) 山口 豊, 佐藤展将, 室田欣宏, 等 : 肺癌一肺癌 切除例における所属リンパ節の役割一, 肺と心, $30(1): 15-23,1983$.

3）山口豊，佐藤展将，木村秀樹，等：肺癌のリン 八゚節郭清, 外科診療, $25(2): 145-152,1983$.

4）山口 豊，藤沢武彦，木村秀樹，等：肺癌の外科 治療一治療成績向上対策について一，日胸，43 (4) :261-268, 1984.

5）山口 豊，木村秀樹：肺癌治療のプロトコール， 臨外, 42(6): 1017-1025, 1987.

6）西山祥行，梶田正文，矢野平一，等：CT による 肺癌縦隔リンパ節転移の診断一肺癌切除63例を中 心に一, 肺癌, 25:977-985, 1985.
7）森 清志, 沢口研二，森山紀之，等：肺癌の術前 評価における胸部 $\mathrm{CT}$ と胸部X線診断, 肺癌, 26:381-390, 1986.

8）山下長司郎，坪田紀明，青垣内龍太，等 : 肺癌に おける縱隔リンパ節の CT 診断の評価, 肺癌, 27 (2)/146-161, 1987.

9）三谷唯章，下高原哲郎，山王邦博，等 : 肺癌の縦 隔リンパ節転移に対する CT 診断一領域別郭清リ ンパ節と CT 所見との対比検討一, 肺癌, $26(6)$ : 643-649, 1986.

10）山口 豊, 岩井直路, 木村秀樹, 等 : 画像診断に よる術前評価診断, CURRENT THERAPY, 4 (12) :37-41, 1986.

11）渡辺洋宇, 佐藤日出夫, 飯田茂穂, 等 : 肺癌にお ける T-, N-因子の術前評価の正診率一開胸例に ついての術後評価との比較一肺癌, $24(2): 165$ 173, 1984.

12）西山祥行, 西脇 裕, 児玉哲郎, 等: 肺癌におけ る $\mathrm{T}$ 因子, N因子の術前評価の検討一 CT スキャ ン使用, 未使用例の比較一, 肺癌, $27(2)$ ：155161, 1987.

13) Daly BDT. jr, Faling LJ, Pugatch RD, et al: Computed tomography-An effective technique for mediditinal staging in lung cancer, $\mathrm{J}$ Thorac Cardiovasc Surg, 88: 486-494, 1984.

14) Breyer RH, Karstaedt N, Mills SA, et al: Computed tomography for evaluation of mediastinal lymph node in lung cancer: Correlation with surgical staging, Ann Thoracic Surg, 38 : 215-220, 1984.

15) Mckenna RJ jr, Libshitz HI, Mountain CE, et al: Roentgenographic evaluation of mediastinal 
nodes for preoperative assessment in lung cancer, Chest, 88: 206-210, 1985.

16) Libshitz HI, McKenna RJ jr: Mediastinal lymph node size in lung cancer. AJR, 143: 715-718, 1984.

17) DiMagno EP, Buxton JL, Regan PT, et al: Ultraso-nic endoscope, Lancet, 22: 629-631, 1980.

18）蔵本純一，広崎晃雄，西平哲郎，等：食道的緹隔 超音波断層法ァ食道エコー）による食道癌縦隔内 リンパ節転移の術前診断, 日胸外会誌, $30: 197-$ 197, 1982.

19）荻野幸伸：リニア型超音波内視鏡による食道疾患 診断の研究, Gastroenterological Endoscopy, 27 (1) 3-13, 1985.

20）斉藤典男，奥井勝二：経直腸的超音波断層法によ る直腸癌彮断に関する研究，大腸肍門誌， 37 : 228-240, 1984.
21）笠島 学, 山本恵一, 龍村俊樹, 等: 経食道超音 波内視鏡による肺癌の縦隔浸潤の観察, 映像情報 18 : 989-994, 1986.

22）檀原 高，小林英夫：脑部疾患に打ける経食道的 超音波内視鏡の応用，日胸，46(4)：266-277， 1987.

23) Glazer GM, Gross BH, Quint LE, et al: Normal mediastinal lymph nodes: Number and size according to american thoracic society mapping, AJR, 144 : 261-265, 1985.

24) Genereux GP, Howie JL: Normal mediastinal lymph node size and number: CT and anatomic study. AJR, 142 : 1095-1100, 1984.

25）伊藤忠彦，相部 剛，吉田智治，等：超音波内視 鏡による食道癌の深達度診断およびリンパ節転移 の検討 Gastroenterological Endoscopv, 28(6) : 1193-1201, 1986. 


\title{
Transesophageal Endoscopic Ultrasonography for Preoperative Assessment of the N-Factor in Lung Cancer
}

\author{
Hidehiko Sakio and Yutaka Yamaguchi \\ Department of Surgery, Institute of Pulmonary Cancer Research, School of Medicine, \\ Chiba University, Chiba, Japan
}

The evaluation of mediastinal nodal metastasis is important in the assessment of the operative indications and prognosis in patients with lung cancer. Various procedures are used to determine nodal metastasis preoperatively, but the level of accuracy is not satisfactory.

In this study, transesophageal endoscopic ultrasonography (E-EUS) was used to assess $\mathrm{N}$-factors, especially mediastinal nodal metastasis, in 32 patients who had had resections of cancers of the left lung. The usefulness of E-EUS was evaluated. An ultrasonic probe with a $5 \mathrm{MHz}$ linear array transducer, $12 \mathrm{~mm}$ in diameter and $40 \mathrm{~mm}$ in length, was attached to the tip of an esophagofiberscope for this study. Mediastinal and hilar lymph nodes were identified with the use of images of the heart and great vessels as landmarks. The outline of lymph nodes was clearly and continously visible on E-EUS. so the long and short dimensions of a node could be measured easily on the image in which it was largest.

Nodes in which the average of the two dimensions was $10 \mathrm{~mm}$ or more were considered to have metastases. In E-EUS, the visual field was greatly restricted by various obstructing factors, such as air tracheal or bronchial cartilages and calcifications. Generally, only \#5 (subaortic) and \#7 (subcarinal) nodes could be demonstrated. There we investigated primarily these two portions in this study.

The reliability of E-EUS diagnosis of metastasis to $\# 5$ or $\# 7$ nodes was as follows. In $\# 5$ node, the sensitivity, specificity, and accuracy were $85.7 \%, 80.0 \%$ and $81.3 \%$, respectively; these results are superior to those of $\mathrm{CT}$ scans. In $¥ 7$ node, they were $100 \%, 93.1 \%$ and $93.8 \%$, respectively, almost the same as with the $\mathrm{CT}$ scan.

We conclude that E-EUS is more useful in the assessment of mediastinal $\# 5$ nodal metastasis than CT scans in spite of its restricted visual field. Employing the average of the long and short dimensions of $10 \mathrm{~mm}$ as the cut-off point for determining the presence of metastases seems appropriate, but it was difficult to demonstrate the presence of nodal metastasis from the characteristics of the nodal ultrasonographic findings themselves. 